Article

\title{
Immunomodulatory Effect of Stichopus japonicus Acid Mucopolysaccharide on Experimental Hepatocellular Carcinoma in Rats
}

\author{
Yang Song ${ }^{1, *}$, Shou-Jie Jin ${ }^{1}$, Lian-Hua Cui ${ }^{1}$, Xiao-Jun $\mathrm{Ji}^{2}$ and Fu-Guo Yang ${ }^{1}$ \\ 1 Institute of Nutrition, Qingdao University Medical College, Qingdao 266021, Shandong, China; \\ E-Mails: qdjinshj@163.com (S.-J.J.); qdlhcui@163.com (L.-H.C.); yfuguo@126.com (F.-G.Y.) \\ 2 The Affiliated Hospital of Qingdao University Medical College, Qingdao 266021, Shandong, \\ China; E-Mail: jixiaojun123@126.com
}

* Author to whom correspondence should be addressed; E-Mail: qdsongyang@126.com; Tel./Fax: +86-0532-8299-1037.

Received: 3 May 2013; in revised form: 17 May 2013 / Accepted: 9 June 2013 /

Published: 19 June 2013

\begin{abstract}
Stichopus japonicus acid mucopolysaccharide (SJAMP) is an important biologically active compound that can be extracted from the body wall of the sea cucumber. The present study investigated the anti-tumor and immunomodulatory effects of SJAMP in an experimental hepatocellular carcinoma (HCC) model in rats. Three doses of SJAMP (17.5 mg/kg, $35 \mathrm{mg} / \mathrm{kg}$, and $70 \mathrm{mg} / \mathrm{kg}$ administered 5 days/week via oral gavage) were given to rats with diethylnitrosamine (DEN)-induced HCC. SJAMP treatment significantly inhibited DEN-induced HCC by reducing both the number and mean volume of nodules, decreasing serum $\alpha$-fetoprotein (AFP) levels and proliferating cell nuclear antigen (PCNA) expression in liver, and increasing p21 expression. Furthermore, SJAMP decreased the serum levels of ALT, AST, GGT and TNF- $\alpha$ and increased serum IL-2. SJAMP administration also improved indices of spleen and thymus function and improved both macrophage phagocytosis and NK cell-mediated tumoricidal activity. Moreover, $\mathrm{CD}^{+}{ }^{+}$and $\mathrm{CD}^{+} \mathrm{T}$ lymphocyte levels recovered significantly and the $\mathrm{CD}^{+} / \mathrm{CD}^{+} \mathrm{T}$ cell ratio normalized in a dose-dependent manner. In conclusion, SJAMP effectively inhibited the growth of HCC through the stimulation of immune organs and tissue proliferation, leading to the enhancement of cellular immunity pathways in rats.
\end{abstract}


Keywords: hepatocellular carcinoma; Stichopus japonicus acid mucopolysaccharide; macrophage; natural killer cell; T lymphocyte subsets; proliferating cell nuclear antigen; p21 expression

\section{Introduction}

Hepatocellular carcinoma (HCC) is one of the most lethal human cancers and the third leading cause of cancer mortality worldwide, resulting in some 600,000 deaths annually [1]. Despite significant advances in surgery and radiotherapy, not all patients respond fully to therapeutic intervention. Furthermore, traditional chemotherapeutic drugs have several deficiencies including poor specificity, side effects and low tolerability. The enhancement of the host's immune response has been recognized as a possible means of inhibiting tumor growth without harm to the host [2]. Therefore, the study of novel natural biochemical materials that have anti-tumor activity and immunostimulatory properties has piqued the interests of many researchers.

Sea cucumbers are marine animals that are important as a human food source, particularly in some parts of Asia. They are typically soft-bodied echinoderms comprising a diverse group of flexible, elongated, worm-like organisms with leathery skin and a gelatinous body that resembles a cucumber [3]. A multitude of harvestable sea cucumber species have been developed to meet the growing global demand for their food and pharmaceutical properties. Stichopus japonicus acid mucopolysaccharide (SJAMP) is an important biologically active compound that is extracted from the body wall of the sea cucumber Stichopus japonicus. SJAMP is made up of galactosamine, hexuronic acid, fucose and sulfuric acid with a proportion of 1:1:1:4 [4-6]. SJAMP has multiple pharmacologic properties, including anti-tumor, immunologic regulation, anticoagulant and antiviral properties [3]. Previous studies have shown that SJAMP has protective effects against several cancers and inhibits the proliferation of malignant cells through the induction of apoptosis [7,8]. To date, studies of the antitumor effect of SJAMP in vitro have mainly focused on several different types of tumor cells, including HeLa, lung cancer, stomach cancer and liver cancer cells [4,7,8]. However, the mechanisms of the anti-tumor activity of SJAMP remain largely unexplored.

There is a close relationship between immune functional status and the occurrence and progression of tumors [9-12]. Tumor cells that develop mechanisms against normal immune response, they may become pathogenic tumors, while down-regulation of the immune response in tumor-bearing patients may result in further tumor development, up-regulaton has been shown to be a useful therapeutic approach [13]. Immunotherapy is a relatively novel approach to tumor therapy. However, numerous immune tolerogenic factors induced by viral infection or a chronic inflammatory response during hepatocyte carcinogenesis may accumulate, facilitating an aggressive and effective counterattack against the anti-HCC immunity of the host [14]. In developing tumors anti-tumorigenic and pro-tumorigenic immune and inflammatory mechanisms coexist [15]. Although the proinflammatory signaling cascades that mediate the pro-tumorigenic effects of inflammation are often activated during HCC development $[15,16]$, immunomodulatory agents including those to release immune suppression and boost anti-HCC immunity are promising [14]. 
In our current study, we therefore investigated the anti-tumor and immunomodulatory activities of SJAMP in a diethylnitrosamine (DEN)-induced HCC rat model. The results may help provide an experimental and theoretical basis for the study of the anti-tumor effects of SJAMP.

\section{Results and Discussion}

\subsection{Growth Conditions of the Rats in the Feeding Process}

Rats in the normal control group produced normal urine and showed significant gains in weight, good gloss and high-quality fur. After eight weeks of feeding to produce long-term exposure to DEN, rats in the tumor control group displayed signs of poor health, including apathy, dull coats, gloss loss, loss of appetite, reduced activity and slow growth. Rats in the SJAMP intervention groups were distinctly better than those in the tumor control group. During the course of the experiment, three rats died in the tumor control group, and one rat died in each of the low-SJAMP-dose group and the medium-SJAMPdose groups. Table 1 shows the body weight changes of the animals in each group. There were no significant differences in mean body weight among the groups at baseline $(p>0.05)$. At the termination of the experiment (at the 16th week), the final mean body weight of the rats in the DEN-induced tumor control group was significantly lower than the normal control group $(p<0.05)$. The final mean body weight of the rats in the high-SJAMP-dose group was significantly higher than in the tumor control group $(p<0.05)$. The low- or medium-SJAMP-dose groups also had increased mean final body weights compared to the tumor control group, although the increase did not reach statistical significance.

Table 1. Weight change of rats over the experimental period $(\bar{x} \pm \mathrm{SD})$.

\begin{tabular}{ccccc}
\hline Groups & $\begin{array}{c}\text { Number } \\
(\mathbf{n})\end{array}$ & $\begin{array}{c}\text { Deaths } \\
(\mathbf{n})\end{array}$ & $\begin{array}{c}\text { Pre-experimental } \\
(\mathbf{g})\end{array}$ & $\begin{array}{c}\text { Post-experimental } \\
(\mathbf{g})\end{array}$ \\
\hline Normal control & 10 & 0 & $197.4 \pm 20.3$ & $566.9 \pm 73.1$ \\
Tumor control & 10 & 3 & $202.4 \pm 27.2$ & $441.3 \pm 50.3^{\mathrm{a}}$ \\
Low SJAMP dose $(17.5 \mathrm{mg} / \mathrm{kg})$ & 10 & 1 & $197.0 \pm 22.5$ & $460.7 \pm 52.4^{\mathrm{a}}$ \\
Medium SJAMP dose $(35 \mathrm{mg} / \mathrm{kg})$ & 10 & 1 & $192.7 \pm 18.9$ & $476.6 \pm 41.8^{\mathrm{a}}$ \\
High SJAMP dose $(70 \mathrm{mg} / \mathrm{kg})$ & 10 & 0 & $208.5 \pm 16.9$ & $509.5 \pm 26.7^{\mathrm{ab}}$ \\
\hline \multicolumn{4}{c}{$p<0.05 v$ s. normal control group; ${ }^{\mathrm{b}} p<0.05 v$ s. tumor control group. }
\end{tabular}

\subsection{The Inhibitory Effect of SJAMP on Tumor Growth in Rats with DEN-Induced HCC}

Visible nodules were found in all tumor control and SJAMP intervention groups. Compared to the tumor control group, medium $(35 \mathrm{mg} / \mathrm{kg})$ and high $(70 \mathrm{mg} / \mathrm{kg})$ SJAMP dose significantly reduced the number of nodules greater than $3 \mathrm{~mm}$ and $5 \mathrm{~mm}$ in diameter, respectively (Table $2 ; p<0.05$ ). The low SJAMP dose also decreased the number of nodules compared with the tumor control group, but the reduction did not reach statistical significance. The mean volume of the largest nodules in the SJAMP intervention groups were significantly less than in the tumor control group $(p<0.05)$. Figure 1 shows the histopathological changes in the liver tissues of the rats in the different groups. In the livers from normal control group rats, hepatic lobules were structurally intact, hepatic cords were arranged in neat rows, and nuclei were clearly visible (Figure 1A). Livers from tumor control group rats showed characteristics of Hepatocellular carcinoma or neoplasm, including obvious nodular liver lesions, 
irregularly shaped or spindle-shaped cell changes, plentiful tumor vessels, varying degrees of fatty degeneration, hyperchromatic and prominent nuclei and mitosis (Figure 1B). There were different degrees of pathological changes in the liver tissues of the rats in the SJAMP intervention groups. No significant differences between the low-SJAMP-dose group (Figure 1C) and the tumor control group were observed (Figure 1B). However, the hepatic lobules were arranged neatly with only slight steatosis and floating cancer cells in the medium-SJAMP-dose (Figure 1D) and high-SJAMP-dose groups (Figure 1E).

Table 2. Effect of SJAMP intervention on liver tumor incidence $(\bar{x} \pm \mathrm{SD})$.

\begin{tabular}{|c|c|c|c|c|}
\hline Groups & $\begin{array}{c}\text { Number } \\
\text { (n) }\end{array}$ & $\begin{array}{c}\text { Average number } \\
\text { of nodules/ } \\
\text { nodule-bearing } \\
\text { liver }(>\mathbf{3} \mathbf{~ m m})\end{array}$ & $\begin{array}{c}\text { Average number } \\
\text { of nodules/ } \\
\text { nodule-bearing } \\
\text { liver }(>5 \mathrm{~mm})\end{array}$ & $\begin{array}{c}\text { Maximum } \\
\text { nodule } \\
\text { volume } \\
\left(\mathbf{m m}^{3}\right)\end{array}$ \\
\hline Normal control & 10 & - & - & - \\
\hline Tumor control & 7 & $38.1 \pm 13.5$ & $4.3 \pm 1.1$ & $178.77 \pm 58.56$ \\
\hline Low SJAMP dose $(17.5 \mathrm{mg} / \mathrm{kg})$ & 9 & $37.8 \pm 12.3$ & $3.9 \pm 0.8$ & $116.14 \pm 28.18^{\mathrm{a}}$ \\
\hline Medium SJAMP dose (35 mg/kg) & 9 & $30.4 \pm 8.1^{\mathrm{a}}$ & $3.1 \pm 0.6^{\mathrm{a}}$ & $89.65 \pm 25.42^{\mathrm{a}}$ \\
\hline High SJAMP dose $(70 \mathrm{mg} / \mathrm{kg})$ & 10 & $26.1 \pm 11.1^{\mathrm{ab}}$ & $2.6 \pm 1.1^{\mathrm{ab}}$ & $66.37 \pm 18.00^{\mathrm{ab}}$ \\
\hline
\end{tabular}

Figure 1. H\&E-stained liver tissue biopsies from rats by experimental group (magnification factor $\times$ 400). (A) normal control group; (B) tumor control group; (C) low-SJAMP-dose group (17.5 mg/kg); (D) medium-SJAMP-dose group (35 mg/kg); (E) high-SJAMP-dose group (70 mg/kg).

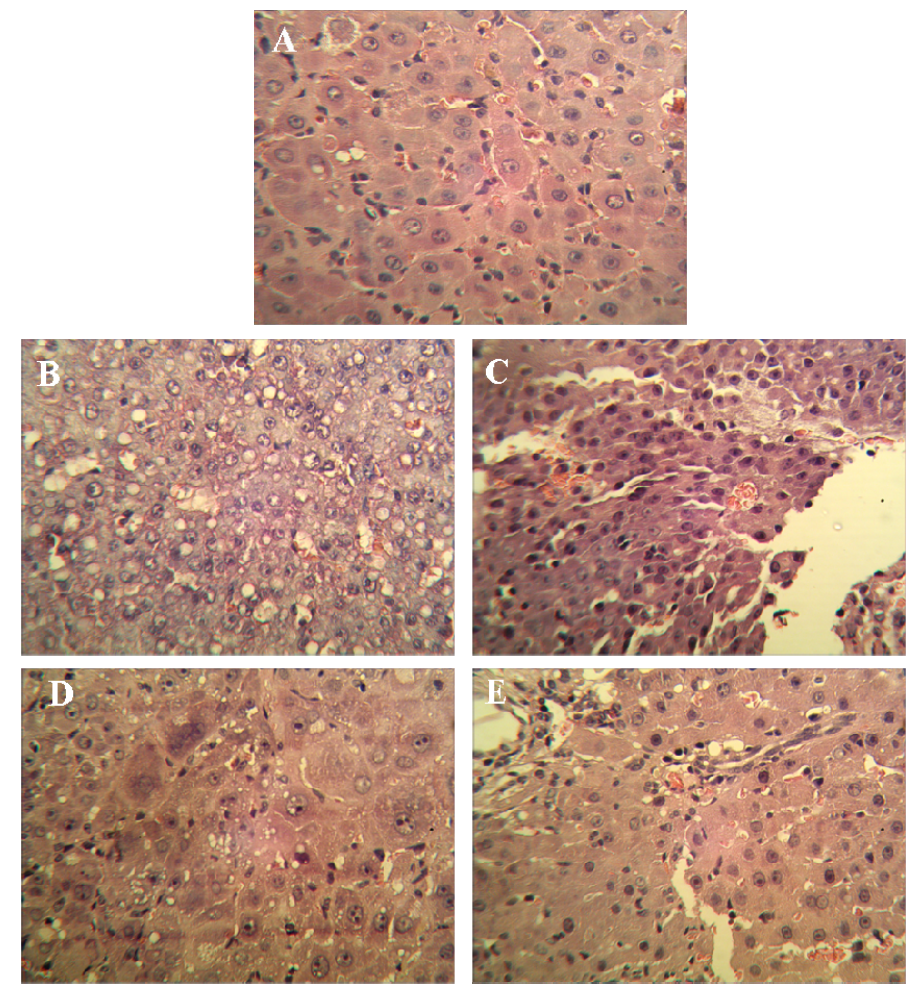


DEN-induced HCC in animals is one of the best-characterized experimental models of HCC, and it is widely used to investigate hepatocarcinogenesis and to screen potential anti-HCC compounds [17-19]. Our results clearly indicate that SJAMP was able to reduce not only the number of DEN-induced HCC lesions but also the volume of the largest nodules in each individual rat with HCC. This finding is of critical importance because a liver affected with HCC usually contains multiple malignant foci, and the existence of multiple small foci is the most common factor leading to the recurrence of HCC. Higher doses of SJAMP also led to greater anti-tumor effects, further supporting the effectiveness of SJAMP as an anti-HCC agent.

\subsection{The Effect of SJAMP on Liver Injury and Cancer Markers in Rats with DEN-Induced HCC}

The effect of SJAMP on liver injury is shown in Table 3. Levels of serum alanine aminotransferase (ALT), aspartate aminotransferase (AST) and $\gamma$-glutamyltranspeptidase (GGT) were significantly increased in the DEN-induced tumor control group compared to the normal control group $(p<0.01)$. These factors were significantly decreased in the SJAMP intervention groups relative to the normal control group $(p<0.01)$, and showed a clear dose-response relationship. Figure 2 depicts the levels of the tumor marker Alpha-fetoprotein (AFP) in serum as assessed by an ELISA assay. While in the DEN-induced tumor control group there was a marked increase in AFP level compared to the normal control group, the levels of AFP were significantly reduced in the medium-SJAMP-dose group and high-SJAMP-dose group compared with the tumor control group ( $p<0.05$ and $p<0.01$, respectively). The low-SJAMP-dose group also reduced the serum AFP level, but this was not statistically significant relative to the tumor control group.

The increase in serum ALT, AST and GGT indicated that DEN may induce acute liver injury. During carcinogenesis, these enzymes could be used as biomarkers of HCC response to therapy. As seen in the present study, treatment with SJAMP significantly reduced serum ALT, AST and GGT levels compared to DEN-treated animals, which suggests that SJAMP may be a potential protective agent against the liver toxicity of DEN.

AFP has been widely used as a clinical marker in the diagnosis and monitoring of HCC. In our study, there was a marked increase in serum AFP level in DEN-induced tumor control group animals. This finding is consistent with previous report that DEN-induced HCC in rats led to an increase in serum AFP [20]. The medium and high doses of SJAMP significantly reduced serum AFP level, suggesting that SJAMP might deaden lesion of the liver and delay the DEN-induced HCC in rats.

Table 3. Effect of SJAMP on the levels of serum ALT, AST and GGT in rats with DEN-induced HCC $(\bar{x} \pm \mathrm{SD})$.

\begin{tabular}{ccccc}
\hline Groups & $\begin{array}{c}\text { Number } \\
(\mathbf{n})\end{array}$ & $\begin{array}{c}\text { ALT } \\
(\mathbf{U} / \mathbf{L})\end{array}$ & $\begin{array}{c}\text { AST } \\
(\mathbf{U} / \mathbf{L})\end{array}$ & $\begin{array}{c}\text { GGT } \\
(\mathbf{U} / \mathbf{L})\end{array}$ \\
\hline Normal control & 10 & $63.44 \pm 10.42$ & $139.00 \pm 27.92$ & $7.70 \pm 5.76$ \\
Tumor control & 7 & $96.57 \pm 28.62^{\mathrm{a}}$ & $394.86 \pm 34.01^{\mathrm{a}}$ & $126.71 \pm 18.37^{\mathrm{a}}$ \\
Low SJAMP dose $(17.5 \mathrm{mg} / \mathrm{kg})$ & 9 & $202.67 \pm 25.59^{\mathrm{b}}$ & $301.11 \pm 30.84^{\mathrm{b}}$ & $98.67 \pm 16.40^{\mathrm{b}}$ \\
Medium SJAMP dose $(35 \mathrm{mg} / \mathrm{kg})$ & 9 & $223.00 \pm 29.80^{\mathrm{b}}$ & $260.11 \pm 27.72^{\mathrm{b}}$ & $96.67 \pm 11.34^{\mathrm{b}}$ \\
High SJAMP dose $(70 \mathrm{mg} / \mathrm{kg})^{\mathrm{y}}$ & 10 & $166.70 \pm 23.25^{\mathrm{b}}$ & $239.80 \pm 34.58^{\mathrm{b}}$ & $86.80 \pm 16.38^{\mathrm{b}}$ \\
\hline
\end{tabular}

${ }^{\mathrm{a}} p<0.01$ vs. normal control group; ${ }^{\mathrm{b}} p<0.01$ vs. tumor control group. 
Figure 2. Effect of SJAMP on the levels of serum AFP in rats with DEN-induced HCC. (A) normal control group; (B) tumor control group; (C) low-SJAMP-dose group (17.5 mg/kg);

(D) medium-SJAMP-dose group (35 mg/kg); (E) high-SJAMP-dose group (70 mg/kg). Data are expressed as the means $\pm \mathrm{SD} .{ }^{*} p<0.01$ vs. normal control group; ${ }^{*} p<0.05$, \#\# $p<0.01$ vs. tumor control group, respectively.

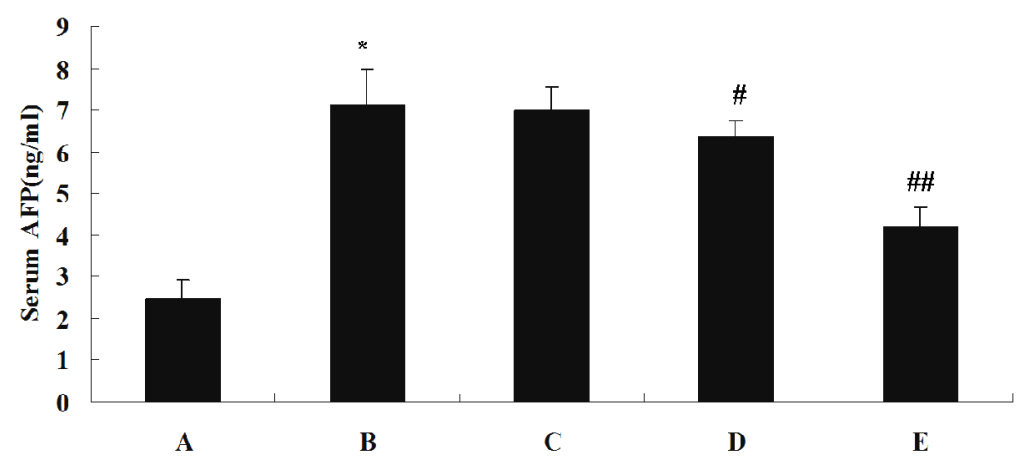

\subsection{The Effect of SJAMP on the Expression of PCNA and p21 in Rats with DEN-Induced HCC}

The expression of PCNA and p21 was examined by immunohistochemistry (IHC) in livers of all groups. Figure 3 shows representative IHC staining results for proliferating cell nuclear antigen (PCNA) and p21. As shown in Table 4, the PCNA labeling index was significantly increased, whereas p21-positive cells were dramatically decreased in the DEN-induced tumor control group rats compared to rats in the normal control group $(p<0.05)$. Compared with the DEN-induced tumor control group, the PCNA labeling indices of the SJAMP intervention groups were decreased $(p<0.05)$, while $\mathrm{p} 21$-positive cells of the SJAMP intervention groups were increased $(p<0.05)$ in a clear dose-response manner.

Figure 3. Representative photographs for immunohistochemical staining studies of PCNA and p21. (A) PCNA-stained cells (indicated with arrows) in normal control group, tumor control group and high-SJAMP-dose group (magnification factor $\times 200$ ); (B) p21-stained cells (indicated with arrows) in normal control group, tumor control group and high-SJAMP-dose group (magnification factor $\times 400$ ).

$\mathbf{A}$

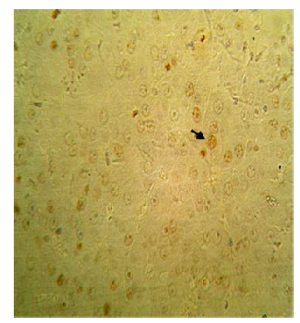

normal control

B

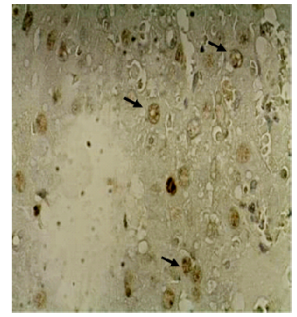

normal control

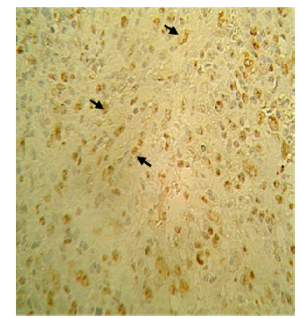

tumor control

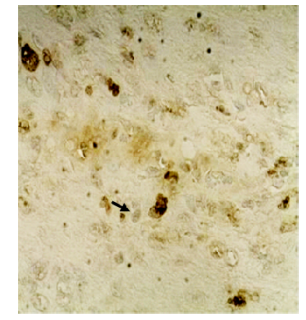

tumor control

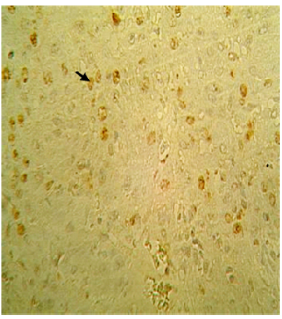

high SJAMP dose

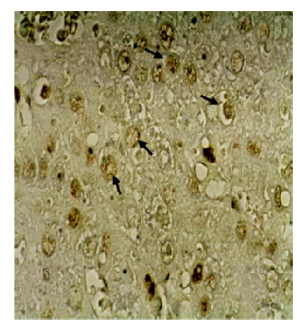

high SJAMP dose 
Table 4. Effect of SJAMP on PCNA labeling index and p21-positive cells in rats with DEN-induced HCC $(\bar{x} \pm \mathrm{SD})$.

\begin{tabular}{cccc}
\hline Groups & Number (n) & PCNA (\%) & P21 (\%) \\
\hline Normal control & 10 & $30.30 \pm 5.46$ & $35.43 \pm 4.20$ \\
Tumor control & 7 & $59.71 \pm 3.35^{\mathrm{a}}$ & $16.40 \pm 3.78^{\mathrm{a}}$ \\
Low SJAMP dose $(17.5 \mathrm{mg} / \mathrm{kg})$ & 9 & $50.56 \pm 3.64^{\mathrm{b}}$ & $20.30 \pm 2.50^{\mathrm{b}}$ \\
Medium SJAMP dose $(35 \mathrm{mg} / \mathrm{kg})$ & 9 & $46.11 \pm 3.72^{\mathrm{b}}$ & $25.00 \pm 2.35^{\mathrm{b}}$ \\
High SJAMP dose $(70 \mathrm{mg} / \mathrm{kg})$ & 10 & $42.00 \pm 3.65^{\mathrm{b}}$ & $29.44 \pm 2.88^{\mathrm{b}}$ \\
\hline \multicolumn{4}{c}{${ }^{\mathrm{a}} p<0.05 v$ s. normal control group; ${ }^{\mathrm{b}} p<0.05 v s$. tumor control group. }
\end{tabular}

Abnormal cell proliferation is the main feature of carcinogenesis, making inhibition of the excessive proliferation of tumor cells is an effective treatment approach. PCNA, a marker of cell proliferation, is associated with the DNA synthesis phase of the cell cycle [21,22]. p21, a tumor suppressor protein, exerts an inhibitory effect upon cell growth by binding to PCNA [23]. Our results demonstrated an anti-proliferative effect of SJAMP in hepatic tissue, which may, in part, account for its inhibitory effects on DEN-induced hepatocarcinogenesis.

\subsection{The Effect of SJAMP on Immune Organs in Rats with DEN-Induced HCC}

Mean immune organ indices are shown in Table 5. The mean thymus index of the tumor control group was significantly lower than in the normal control group $(p<0.05)$, but the mean thymus indices in the SJAMP intervention groups were higher than the tumor control group in a clear dose-response manner. Although the mean thymus index of the low-SJAMP-dose group was increased compared to the tumor control group, the increase did not reach statistical significance. The mean spleen index of the tumor control group was significantly higher than that of the normal control group $(p<0.05)$, indicating that the rats could mobilize their own immune organs to defend against external toxins when attacked by external challenges. The mean spleen indices in the SJAMP intervention groups were higher than in the tumor control group in a clear dose-response manner. There were no significant differences in these indices between the low-SJAMP-dose group and the tumor control group, however. Collectively, these results suggest that SJAMP can stimulate and promote growth of the spleen and thymus.

Table 5. Effect of SJAMP on thymus and spleen indices in rats with DEN-induced HCC $(\bar{x} \pm \mathrm{SD})$.

\begin{tabular}{|c|c|c|c|}
\hline Groups & Number (n) & Thymus index & Spleen index \\
\hline Normal control & 10 & $0.965 \pm 0.159$ & $1.165 \pm 0.226$ \\
\hline Tumor control & 7 & $0.571 \pm 0.167^{\mathrm{a}}$ & $3.364 \pm 0.770^{\mathrm{a}}$ \\
\hline Low SJAMP dose $(17.5 \mathrm{mg} / \mathrm{kg})$ & 9 & $0.706 \pm 0.199^{\mathrm{a}}$ & $3.491 \pm 0.991^{\mathrm{a}}$ \\
\hline Medium SJAMP dose (35 mg/kg) & 9 & $0.928 \pm 0.225^{\mathrm{b}}$ & $4.418 \pm 0.601^{\mathrm{ab}}$ \\
\hline High SJAMP dose $(70 \mathrm{mg} / \mathrm{kg})$ & 10 & $0.994 \pm 0.173^{\mathrm{b}}$ & $5.569 \pm 0.969^{\mathrm{ab}}$ \\
\hline
\end{tabular}




\subsection{The Effect of SJAMP on Phagocytosis by Spleen Macrophages in Rats with DEN-Induced HCC}

As shown in Table 6, the phagocytic activity of macrophages was improved in all of the tumor control and SJAMP intervention groups compared to the normal control group, and the SJAMP intervention groups showed the highest macrophage phagocytic activity $(p<0.01)$. Although the increase in the macrophage phagocytic activity in the low-SJAMP-dose group did not reach statistical significance compared to the tumor control group, there did appear to be a dose-response relationship between SJAMP intervention dose and phagocytic activity of the macrophages. Phagocytosis is one of the most important functions of macrophages in anti-tumor immunity [24]. Our results suggest that SJAMP could enhance immune function in rats with DEN-induced HCC.

Table 6. Effect of SJAMP on the phagocytic activity of macrophage and the cytotoxic activity of NK cells in rats with DEN-induced $\mathrm{HCC}(\bar{x} \pm \mathrm{SD})$.

\begin{tabular}{cccc}
\hline Groups & $\begin{array}{c}\text { Number } \\
\text { (n) }\end{array}$ & $\begin{array}{c}\text { Phagocytic activity of } \\
\text { macrophages } \\
\text { (OD value) }\end{array}$ & $\begin{array}{c}\text { Cytotoxic activity of } \\
\text { NK cells } \\
\text { (\%) }\end{array}$ \\
\hline Normal control & 10 & $0.078 \pm 0.003$ & $40.8 \pm 5.7$ \\
Tumor control & 7 & $0.122 \pm 0.012^{\mathrm{a}}$ & $22.3 \pm 10.4^{\mathrm{a}}$ \\
Low SJAMP dose $(17.5 \mathrm{mg} / \mathrm{kg})$ & 9 & $0.125 \pm 0.008^{\mathrm{a}}$ & $25.1 \pm 4.3^{\mathrm{a}}$ \\
Medium SJAMP dose $(35 \mathrm{mg} / \mathrm{kg})$ & 9 & $0.139 \pm 0.015^{\mathrm{ab}}$ & $29.0 \pm 4.5^{\mathrm{ab}}$ \\
High SJAMP dose $(70 \mathrm{mg} / \mathrm{kg})$ & 10 & $0.144 \pm 0.011^{\mathrm{ab}}$ & $41.3 \pm 6.9^{\mathrm{b}}$ \\
\hline
\end{tabular}

${ }^{\mathrm{a}} p<0.01 v s$. normal control group; ${ }^{\mathrm{b}} p<0.01 v s$. tumor control group.

\subsection{The Effect of SJAMP on the Cytotoxic Activity of Natural Killer Cells in Rats with} DEN-Induced HCC

As shown in Table 6, while the cytotoxic activity of NK cells in the DEN-induced HCC tumor control group was significantly lower than in the normal control group $(p<0.01)$, the cytotoxic activity of the NK cells in the low-SJAMP-dose group and high-SJAMP-dose group was significantly higher than that of the tumor control group $(p<0.01)$. Although the cytotoxic activity of the NK cells in the low-SJAMP-dose group was increased compared with the tumor control group, the increase did not reach statistical significance. Cytotoxic activity of the NK cells was therefore only restored by higher doses of SJAMP.

As the first line of immune defense against developing tumors, NK cells play an important role in immune surveillance for cancer cells, as they rapidly recognize and lyse a large variety of tumor cells without the help of either prior sensitization or MHC-dependent recognition [25-27]. Our data suggest that SJAMP was an important biological-response modifier of NK cells in vivo.

\subsection{The Effect of SJAMP on Peripheral Blood T-Lymphocyte Subsets in Rats with DEN-Induced HCC}

Peripheral blood T-lymphocyte subsets were analyzed using flow cytometry, and representative results from the tumor control group rats are shown in Figure 4. The percentage of $\mathrm{T}$ lymphocytes from each subset and the $\mathrm{CD} 4^{+} / \mathrm{CD}^{+}$ratios are shown in Table 8 . The $\mathrm{CD}^{+}$and $\mathrm{CD}^{+} \mathrm{T}$ lymphocyte 
levels and $\mathrm{CD}^{+} / \mathrm{CD}^{+}$ratio in the tumor control group were significantly decreased compared to the normal control group $(p<0.05)$, but the level of $\mathrm{CD} 8^{+} \mathrm{T}$ lymphocytes was not significantly decreased $(p>0.05)$. With increasing dose of SJAMP, $\mathrm{CD} 3^{+}, \mathrm{CD}^{+}$and $\mathrm{CD} 8^{+}$cell levels significantly increased, and the ratio of $\mathrm{CD}^{+}$to $\mathrm{CD} 8^{+}$cells also tended to normalize.

$\mathrm{CD}^{+}{ }^{+}$is expressed on the surface of mature $\mathrm{T}$ lymphocytes. Mature $\mathrm{T}$ lymphocytes in the peripheral blood can be divided into $\mathrm{CD} 4^{+} \mathrm{CD} 8^{-}$and $\mathrm{CD} 4^{-} \mathrm{CD} 8^{+}$subgroups according to markers on the cell surface. $\mathrm{CD}^{+} \mathrm{T}$ cells are thought to play an important role in anti-tumor immunology by regulating the differentiation and development of $\mathrm{CD}^{+} \mathrm{T}$ cells. Immune regulation relies mainly on $\mathrm{CD} 4^{+} \mathrm{T}$ cells and $\mathrm{CD}^{+} \mathrm{T}$ cells, and dynamic changes in the $\mathrm{CD} 4^{+} / \mathrm{CD}^{+}$ratio are regarded as an important factor in determining immunity states $[13,28]$. In the present study, we observed that $\mathrm{CD}^{+}$and $\mathrm{CD} 8^{+}$cells experienced significant recoveries and the ratio of $\mathrm{CD} 4^{+} \mathrm{T}$ cells to $\mathrm{CD} 8^{+} \mathrm{T}$ cells tended to normalize after SJAMP treatment, suggesting that SJAMP is capable of improving immune function in these rats.

Figure 4. Examples of scatterplots presenting $\mathrm{CD} 3^{+}, \mathrm{CD} 4^{+}$and $\mathrm{CD} 8^{+}$lymphocyte subsets. (A) Flow cytometric analysis of staining for $\mathrm{CD}^{+}$(x-axis) and $\mathrm{CD}^{+}$(y-axis) cells in the tumor control group. The $\mathrm{CD}^{+}$cells are represented in lower right quadrant, and the $\mathrm{CD} 4^{+}$ cells are represented in the upper left quadrant. The $\mathrm{CD} 3{ }^{+} \mathrm{CD} 4^{+}$cells are represented in the upper right quadrant; (B) Flow cytometric analysis of staining for $\mathrm{CD}^{+}$(x-axis) and $\mathrm{CD}^{+}$ (y-axis) cells in the tumor control group. The $\mathrm{CD}^{+}$cells are represented in the lower right quadrant, and the $\mathrm{CD}^{+}$cells are represented in the upper left quadrant. The $\mathrm{CD} 3^{+} \mathrm{CD} 8^{+}$ cells are represented in the upper right quadrant.
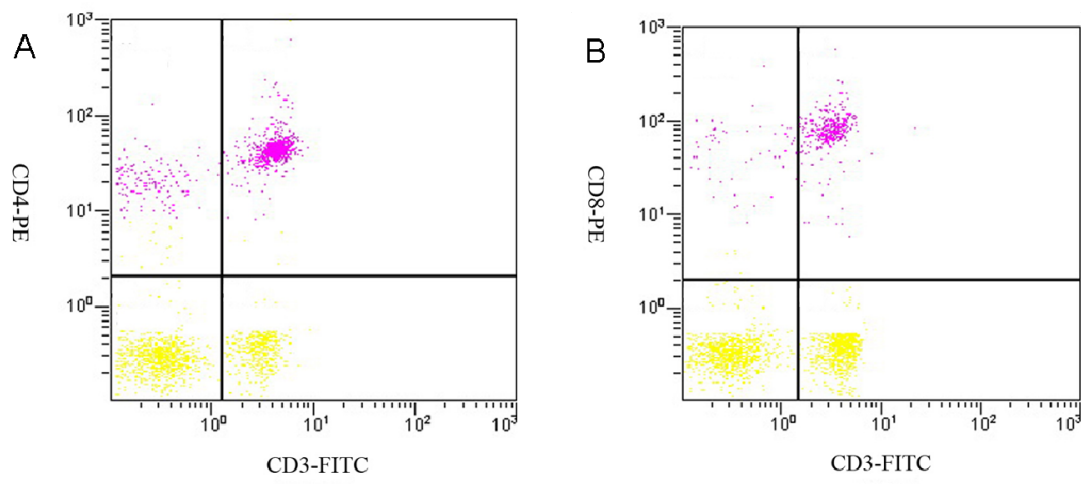

Table 8. Effect of SJAMP on peripheral blood T-lymphocyte subsets in rats with DEN-induced HCC $(\bar{x} \pm \mathrm{SD})$.

\begin{tabular}{ccccc}
\hline Groups & $\mathbf{C D 3}^{+}(\mathbf{\%})$ & $\mathbf{C D 4}^{+}(\mathbf{\%})$ & $\mathbf{C D 8}^{+}(\mathbf{\%})$ & $\mathbf{C D 4}^{+} \mathbf{C D 8}^{+}$ \\
\hline Normal control & $56.078 \pm 10.202^{a}$ & $35.200 \pm 6.165$ & $19.578 \pm 5.398$ & $1.909 \pm 0.650$ \\
Tumor control & $34.150 \pm 12.761^{\mathrm{a}}$ & $18.367 \pm 11.702^{\mathrm{a}}$ & $15.783 \pm 5.010$ & $1.286 \pm 1.103^{\mathrm{a}}$ \\
Low SJAMP dose $(17.5 \mathrm{mg} / \mathrm{kg})$ & $42.671 \pm 10.676^{\mathrm{a}}$ & $23.657 \pm 9.664^{\mathrm{a}}$ & $18.991 \pm 9.969$ & $1.663 \pm 1.208$ \\
Medium SJAMP dose $(35 \mathrm{mg} / \mathrm{kg})$ & $49.250 \pm 8.925^{\mathrm{b}}$ & $29.288 \pm 7.810^{\mathrm{ab}}$ & $19.912 \pm 7.544$ & $1.719 \pm 0.905^{\mathrm{b}}$ \\
High SJAMP dose $\left.(70 \mathrm{mg} / \mathrm{kg})^{\mathrm{a}}\right)$ & $50.288 \pm 11.013^{\mathrm{b}}$ & $29.38 \pm 12.851^{\mathrm{ab}}$ & $20.810 \pm 13.671^{\mathrm{b}}$ & $1.890 \pm 1.145^{\mathrm{b}}$ \\
\hline
\end{tabular}




\subsection{The Effect of SJAMP on Production of Serum Cytokines in Rats with DEN-Induced HCC}

Serum levels of IL-2 and TNF- $\alpha$ in each group are shown in Table 9. Serum IL-2 level was significantly decreased, whereas TNF- $\alpha$ level was found to be dramatically increased in the DEN-induced tumor control group rats compared to rats in the normal control group $(p<0.01)$. The medium and high SJAMP doses significantly increased serum IL-2 and decreased serum TNF- $\alpha$ compared to the tumor control group $(p<0.01)$. The low SJAMP dose also increased serum IL-2 and decreased serum TNF- $\alpha$ compared with the tumor control group, but these changes did not reach statistical significance.

IL-2 is mainly secreted by CD4 ${ }^{+} \mathrm{T}$ cells. As a T cell growth factor and stimulator of NK cells, IL-2 augments the host's cell-mediated anti-tumor immune response [29,30]. In the present study, we observed that serum IL-2 levels tended to normalize after SJAMP treatment, suggesting that SJAMP is capable of stimulating the $\mathrm{T}$ cell and NK cell-mediated immune responses in rats with DEN-induced HCC through enhancement of the production of IL-2.

TNF- $\alpha$ is produced by many cell types including macrophages, $\mathrm{CD} 4^{+} \mathrm{T}$ cells, neutrophils, mast cells, fibroblasts, and tumor cells. As a potent pleiotropic proinflammatory cytokine, TNF- $\alpha$ affects the growth, differentiation, and survival of all cells [31]. Existing evidence indicates that high levels of TNF- $\alpha$ can favor cell survival and tumor progression [32]. In the present experiment, there was a marked increase in serum TNF- $\alpha$ level in DEN-induced tumor control group animals. This finding is consistent with a previous report that DEN-induced HCC in Wistar rats led to an increase in serum TNF- $\alpha$ [33]. The reduced level of TNF- $\alpha$ in rats with DEN-induced HCC by the administration of SJAMP may be related to its anti-tumor activity.

Table 9. Effect of SJAMP on serum cytokines production in rats with DEN-induced HCC $(\bar{x} \pm \mathrm{SD})$.

\begin{tabular}{cccc}
\hline Groups & Number $(\mathbf{n})$ & IL-2(pg/mL) & TNF-a(pg/mL) \\
\hline Normal control & 10 & $451.59 \pm 38.15$ & $11.857 \pm 6.929$ \\
Tumor control & 7 & $107.03 \pm 21.21^{\mathrm{a}}$ & $148.694 \pm 22.186^{\mathrm{a}}$ \\
Low SJAMP dose $(17.5 \mathrm{mg} / \mathrm{kg})$ & 9 & $119.00 \pm 23.88$ & $137.189 \pm 17.133$ \\
Medium SJAMP dose $(35 \mathrm{mg} / \mathrm{kg})$ & 9 & $301.93 \pm 17.73^{\mathrm{b}}$ & $99.310 \pm 18.583^{\mathrm{b}}$ \\
High SJAMP dose $(70 \mathrm{mg} / \mathrm{kg})$ & 10 & $370.50 \pm 34.55^{\mathrm{b}}$ & $92.136 \pm 18.943^{\mathrm{b}}$ \\
\hline \multicolumn{4}{c}{${ }^{\mathrm{a}} p<0.01 v$ s. normal control group; ${ }^{\mathrm{b}} p<0.01 v$ s. tumor control group. }
\end{tabular}

\section{Experimental}

\subsection{Materials}

A total of 50 Wistar mice (SPF grade, male, weighing 130-150 g) were purchased from the Shandong Lukang Laboratory Animal Center (Jining, China, SLXK-Lu20080002). SJAMP (purity > 99.5\%) was provided by the College of Food Science and Engineering, Ocean University of China. The YAC-1 cell line was purchased from the Shanghai Cell Bank of the Chinese Academy of Sciences. Optilyse C lysing solution was purchased from Immunotech (Marseille, France). FITC anti-rat CD3 antibody, PE anti-rat CD4 antibody and PE anti-rat CD8a antibody were purchased from Biolegend (San Diego, CA, 
USA). TNF- $\alpha$ and IL-2 enzyme-linked immunoabsorbent assay (ELISA) kits were obtained from Boster Biological Technology (Wuhan, China). Mouse anti-PNCA was purchased from ZSGB-BIO (Beijing, China). Mouse anti-p21 was purchased from Thermo (Waltham, MA, USA).

\subsection{Experimental Schedules}

Fifty rats were randomly divided into a normal control group, tumor control group, low-SJAMP-dose group, medium-SJAMP-dose group, and high-SJAMP-dose group (10 rats/group). All animal experiments were performed according to the rules and regulations of the Animal Ethics Committee of Qingdao University Medical College, China. Rats in the normal control group were fed a normal diet. Rats in the tumor control group and SJAMP intervention groups received an intragastric administration of a $2 \% \mathrm{DEN}$ saline solution $(10 \mathrm{mg} / \mathrm{kg}$ of body weight) once daily for 5 days/week for a period of 15 weeks. Concurrently, the low-, medium- and high-SJAMP-dose groups were given 17.5, 35, and $70 \mathrm{mg} / \mathrm{kg} /$ day of SJAMP, respectively. The tumor control group received intragastric administration of an equivalent amount of normal saline. Rats were weighed once a week. At the $16^{\text {th }}$ week, all rats were anesthetized with chloral hydrate, and the abdominal aortic blood, liver tissues, spleen and thymus were separated and weighed.

Macroscopically visible nodules greater than $3 \mathrm{~mm}$ or $5 \mathrm{~mm}$ in diameter on the liver surface were recorded. The longest and shortest diameters of the largest tumor nodules were measured using a vernier caliper. Volume of the largest nodules was estimated using the following equation [34]:

$$
\text { nodule volume }\left(\mathrm{mm}^{3}\right)=\pi / 6 \times \mathrm{a} \times \mathrm{b}^{2}
$$

where $\mathrm{a}$ is the longest axis, and $\mathrm{b}$ is the shortest axis).

\subsection{Measurement of Liver Function Parameters, Serum AFP, TNF- $\alpha$ and IL-2 Levels}

Levels of ALT, AST and GGT in each serum sample were measured using a Hitachi 7170A Modular Analytic system. Serum concentrations of AFP, TNF- $\alpha$ and IL-2 were assayed by the ELISA method using commercially available enzyme immunoassay kits, according to the manufacturer specifications.

\subsection{Pathological Histology and Immunohistochemistry}

Liver tissues were collected, embedded in paraffin, cut into slices and stained with hematoxylin and eosin ( $\mathrm{H} \& \mathrm{E})$ for histopathological examination under a microscope. Paraffin-embedded, $5 \mu \mathrm{m}$-thin sections from liver specimens were deparaffinized, blocked with $0.3 \%$ hydrogen peroxide for $10 \mathrm{~min}$ and subjected to antigen retrieval in a steamer for $20 \mathrm{~min}$. The slides were then washed twice with PBS and incubated with primary antibodies of PCNA and p21. Incubation with an appropriate secondary antibody was followed by direct DAB staining and light counterstaining with hematoxylin. Staining procedures strictly followed the supplier's recommendations. The proliferation index was determined as the percentage of positively stained nuclei by counting 1000 cells in field at magnification $\times 200$. p21 was quantified by counting positively stained cells and total number of cells at 10 randomly selected fields from each section at $400 \times$ magnifications, and data are presented as a percentage. 


\subsection{Preparation of Spleen Cell Suspensions}

The spleens of the experimental animals were washed twice with D-Hank's solution to remove blood and other non-specific tissues. Approximately $0.5 \mathrm{~cm}^{3}$ of spleen was split and ground, and the spleen cells were resuspended. Cells were washed twice with D-Hank's solution, and the supernatants were discarded. Five $\mathrm{mL}$ of an $\mathrm{NH}_{4} \mathrm{Cl}$ lysis solution was then added to lyse the erythrocytes. After centrifuging the suspensions at $1,000 \mathrm{rpm}$ for $15 \mathrm{~min}$ at $4{ }^{\circ} \mathrm{C}$, the remaining cells were washed twice with PBS and then resuspended in RPMI 1640 medium supplemented with $10 \%$ fetal calf serum. The cells were then seeded into culture bottles and cultured for $2 \mathrm{~h}$ in a $\mathrm{CO}_{2}$ incubator at $5 \% \mathrm{CO}_{2}$. The vast majority of the adherent cells were macrophages, and the non-adherent cells were mainly mixed spleen lymphocytes.

\subsection{Determination of the Phagocytic Activity of the Macrophages}

Phagocytic ability of macrophages was measured via neutral red dye uptake [35]. Adherent macrophages were released into single-cell suspensions using a $0.25 \%$ trypsin digestion and adjusting the cell density to $1 \times 10^{6}$ cells $/ \mathrm{mL}$. An aliquot of $200 \mu \mathrm{L}$ of the cell suspension was added to each of the wells of a 96-well plate (each sample had three parallel wells) and cultured for $48 \mathrm{~h}$. One hundred $\mu \mathrm{L}$ of the culture medium was then aspirated from each well, $100 \mu \mathrm{L}$ of a $0.1 \%$ neutral red solution was added to each well, and the plate was incubated for $30 \mathrm{~min}$ at $37{ }^{\circ} \mathrm{C}$ in a $5 \% \mathrm{CO}_{2}$ humidified incubator. Finally, the plate was washed three times with PBS, and $100 \mu \mathrm{L}$ of lysis buffer $(0.1 \mathrm{~mol} / \mathrm{L}$ acetic acid:ethanol $=1: 1$ ) was added to each well. The treated plates were stored at $4{ }^{\circ} \mathrm{C}$ in the refrigerator overnight, and the OD value at $492 \mathrm{~nm}$ was determined using an enzyme-labeled instrument.

\subsection{Assessment of NK Cell Cytotoxicity}

A lactate-dehydrogenase (LDH)-release assay was used to measure the NK cell-mediated tumor cytotoxicity. Spleen cells from each rat, prepared as previously described, were used as the effector cells. The NK-sensitive cell line YAC-1 was used as the target cell. Two types of cell suspension were prepared that contained $95 \%$ viable cells based on staining determinations with trypan blue. A $200 \mu \mathrm{L}$ cell suspension that including $100 \mu \mathrm{L}$ of the effector cell suspension $\left(1 \times 10^{6} / \mathrm{mL}\right)$ and $100 \mu \mathrm{L}$ of the target cell suspension $\left(1 \times 10^{5} / \mathrm{mL}\right)$ was added into the wells of 96 -well plates (each sample had three parallel wells). After a 4 -h incubation at $37{ }^{\circ} \mathrm{C}$ in a $5 \% \mathrm{CO}_{2}$ humidified incubator, the plates were centrifuged at 1,500 rpm for $15 \mathrm{~min}$. The supernatants from each well $(100 \mu \mathrm{L})$ were transferred into the corresponding wells of another 96-well plate. One hundred $\mu \mathrm{L}$ of lactic acid hydrogenase substrate mixture was then added to each well. After $6 \mathrm{~min}$, the reactions were stopped with $1 \mathrm{~mol} / \mathrm{L} \mathrm{HCl}$. The OD value of each well was measured at $492 \mathrm{~nm}$. The cytotoxic activity of the NK cells was estimated using the following equation:

$$
\text { cytotoxicity }(\%)=[(E-S) /(M-S)] \times 100 \%
$$

where $E$ represents the experimental release of $\mathrm{LDH}$ activity from the target cells incubated in the presence of the effector cells, $S$ is the spontaneous release of the LDH activity from the target cells alone, and $M$ represents the maximum release of the LDH activity determined by lysing the target cells with $1 \% \mathrm{NP}-40$. 


\subsection{T-lymphocyte Subsets in Rat Peripheral Blood Flow Cytometric Analyses}

Aliquots of $100 \mu \mathrm{L}$ of peripheral blood from each rat were added to Eppendorf tubes containing pre-added monoclonal antibodies against CD3, CD4 and CD8a (anti-CD3-FITC, anti-CD4-PE and anti-CD8-PE) and incubated for $15 \mathrm{~min}$ at room temperature in the dark. The red blood cells were lysed using Optilyse C lysing solution following the manufacturer's instructions. After centrifuging at $1,000 \mathrm{rpm}$ for $10 \mathrm{~min}$ at room temperature in the dark, the samples were washed twice with PBS. Then, the cell sediments were suspended in $0.5 \mathrm{~mL}$ PBS. The prepared suspensions were analyzed on a Cytomics FC 500 flow cytometer (Beckman Coulter). A total of 20,000 cells were analyzed for each sample.

\subsection{Statistics}

All data are expressed as the means \pm SD. The data were statistically analyzed using one-way analysis of variance (ANOVA). Post-hoc comparisons were carried out by the least-significant difference (LSD) test. Probability values lower than 0.05 were considered significant.

\section{Conclusions}

In summary, our results show that SJAMP was effective against HCC. The anti-tumor mechanisms of SJAMP may be characterized as protecting the immune organs, stimulating the proliferation of the tissues from the immune organs and enhancing cell-mediated immunity.

\section{Acknowledgments}

This work was supported by the National Natural Science Foundation of China (Contract No. 81072295).

\section{Conflict of Interest}

The authors declare that they have no conflicts of interest.

\section{References}

1. Gomaa, A.I.; Khan, S.A.; Toledano, M.B.; Waked, I.; Taylor-Robinson, S.D. Hepatocellular carcinoma: Epidemiology, Risk factors and pathogenesis. World J. Gastroenterol. 2008, 14, 4300-4308.

2. Yuan, H.; Song, J.; Li, X.; Li, N.; Dai, J. Immunomodulation and antitumor activity of kappa-carrageenan oligosaccharides. Cancer Lett. 2006, 243, 228-234.

3. Bordbar, S.; Anwar, F.; Saari, N. High-value components and bioactives from sea cucumbers for functional foods-a review. Mar. Drugs 2011, 9, 1761-1805.

4. Lu, Y.; Wang, B.L. The research progress of antitumorous effectiveness of Stichopus japonicus acid mucopolysaccharide in north of China. Am. J. Med. Sci. 2009, 337, 195-198.

5. Fan, H.Z. A new method for separation and purification of acidic mucopolysaccharide from stichopus japonicus. Zhong Yao Tong Bao 1982, 7, 27-29. 
6. Kariya, Y.; Watabe, S.; Kyogashima, M.; Ishihara, M.; Ishii, T. Structure of fucose branches in the glycosaminoglycan from the body wall of the sea cucumber stichopus japonicus. Carbohydr. Res. 1997, 297, 273-279.

7. Lu, Y.; Zhang, B.Y.; Dong, Q.; Wang, B.L.; Sun, X.B. The effects of Stichopus japonicus acid mucopolysaccharide on the apoptosis of the human hepatocellular carcinoma cell line HepG2. Am. J. Med. Sci. 2010, 339, 141-144.

8. Fan, T.J.; Yuan, W.P.; Cong, R.S.; Yang, X.X.; Wang, W.W.; Jing, Z. Studies on the purification of water-soluble holothurian glycosides from Apostichpus japonicus and their tumor suppressing activity. Yaо Xие Xие Bao 2009, 44, 25-31.

9. Budhu, A.; Forgues, M.; Ye, Q.H.; Jia, H.L.; He, P.; Zanetti, K.A.; Kammula, U.S.; Chen, Y.; Qin, L.X.; Tang, Z.Y.; et al. Prediction of venous metastases, recurrence, and prognosis in hepatocellular carcinoma based on a uique immune response signature of the liver microenvironment. Cancer Cell 2006, 10, 99-111.

10. Tsai, J.P.; Chen, H.W.; Cheng, M.L.; Liu, H.K.; Lee, Y.P.; Hsieh, C.L.; Luh, K.T.; Wu, C.W.; Hsu, L.H.; Chao, T.Y.; et al. Analysis of host versus tumor interaction in cancer patients: Opposing role of transforming growth factor-betal and interleu-kin- 6 in the development of in situ tumor immunity. Immunobiology 2005, 210, 661-671.

11. Carl, J.W., Jr.; Liu, J.Q.; Joshi, P.S.; EI-Omrani, H.Y.; Yin, L.; Zheng, X.; Whitacre, C.C.; Liu, Y.; Bai, X.F. Autoreactive T cells escape clonal deletion in the thymus by a CD24-dependent pathway. J. Immunol. 2008, 181, 320-328.

12. Mebius, R.E.; Kraal, G. Structure and function of the spleen. Nat. Rev. Immunol. 2005, 5, 606-616.

13. Liu, Y.; Jiao, F.; Qiu, Y.; Li, W.; Lao, F.; Zhou, G.; Sun, B.; Xing, G.; Dong, J.; Zhao, Y.; Chai, Z.; Chen, C. The effect of Gd@C82(OH)22 nanoparticles on the release of Th1/Th2 cytokines and induction of TNF-alpha mediated cellular immunity. Biomaterials 2009, 30, 3934-3945.

14. Pardee, A.D.; Butterfield, L.H. Immunotherapy of Hepatocellular carcinoma: Unique challenges and clinical opportunities. Oncoimmunology 2012, 1, 48-55.

15. Grivennikov, S.I.; Greten, F.R.; Karin, M. Immunity, inflammation, and cancer. Cell 2010, 140, 833-899.

16. Haybaeck, J.; Zeller, N.; Wolf, M.J.; Weber, A.; Wagner, U.; Kurrer, M.O.; Bremer, J.; Iezzi, G.; Graf, R.; Clavien, P.A.; et al. A lymphotoxin-driven pathway to Hepatocellular carcinoma. Cancer Cell 2009, 16, 295-308.

17. Chen, G.G.; Lai, P.B.; Chak, E.C.; Xu, H.; Lee, K.M.; Lau, W.Y. Immunohistochemical analysis of pro-apoptotic Bid level in chronic hepatitis, hepatocellular carcinoma and liver metastases. Cancer Lett. 2001, 172, 75-82.

18. Amin, A.; Hamza, A.A.; Bajbouj, K.; Ashraf, S.S.; Daoud, S. Saffron: A potential candidate for a novel anticancer drug against hepatocellular carcinoma. Hepatology 2011, 54, 857-867.

19. Rajewsky, M.F.; Dauber, W.; Frankenberg, H. Liver carcinogenesis by diethylnitrosamine in the rat. Science 1966, 152, 83-85.

20. Liu, J.G.; Zhao, H.J.; Liu, Y.J.; Liu, Y.W.; Wang, X.L. Effect of two selenium sources on hepatocarcinogenesis and several angiogenic cytokines in diethylnitrosamine-induced hepatocarcinoma rats. J. Trace. Elem. Med. Biol. 2012, 26, 255-261.

21. Chakraborty, T.; Chatterjee, A.; Rana, A.; Srivastawa, S.; Damodaran, S.; Chatterjee M. Cell proliferation and hepatocarcinogenesis in rat initiated by diethynitrosamine and promoted by 
Phenobarbital: potential roles of early DNA damage and liver metallothionein expression. Life Sci. 2007, 81, 489-499.

22. Oyama, K.; Shiota, G.; Ito, H.; Murawaki, Y.; Kawasaki, H. Reduction of hepatocarcinogenesis by ursodeoxycholic acid in rats. Carcinogenesis 2002, 23, 885-892.

23. Waga, S.; Hannon, G.J.; Beach, D.; Stillman, B. The p21 inhibitor of cyclin-dependent kinases controls DNA replication by interaction with PCNA. Nature 1994, 369, 574-578.

24. Oflazoglu, E.; Stone, I.J.; Gordon, K.A.; Grewal, I.S.; van, Rooijen, N.; Law, C.L.; Gerber, H.P. Macrophages contribute to the antitumor activity of the anti-CD30 antibody SGN-30. Blood 2007, 110, 4370-4372.

25. Kim, H.R.; Lee, K.H.; Park, S.J.; Kim S.Y.; Yang Y.K.; Tae, J.; Kim, J. Anti-cancer activity and mechanistic features of a NK cell activating molecule. Cancer Immunol. Immunother. 2009, 58, 1691-1700.

26. Zerbini, A.; Pilli, M.; Laccabue, D.; Pelosi, G.; Molinari, A.; Negri, E.; Cerioni, S.; Fagnoni, F.; Soliani, P.; Ferrari, C.; Missale, G. Radiofrequency thermal ablation for hepatocellular carcinoma stimulates autologous NK-cell response. Gastroenterology 2010, 138, 1931-1942.

27. Shavit, Y.; Ben-Eliyahu, S.; Zeidel, A.; Beilin, B. Effects of fentanyl on natural killer cell activity and on resistance to tumor metastasis in rats. Dose and timing study. Neuroimmunomodulation 2004, 11, 255-260.

28. Wang, R.F.; Peng, G.; Wang, H.Y. Regulatory T cells and Toll-like receptors in tumor immunity. Semin. Immunol. 2006, 18, 136-142.

29. Nishimura, T.; Iwakabe, K.; Sekimoto, M.; Ohmi, Y.; Yahata, T.; Nakui, M.; Sato, T.; Habu, S.; Tashiro, H.; Sato, M.; et al. Distinct role of antigen-specific T helper type1 (Th1) and Th2 cells in tumor eradication in vivo. J. Exp. Med. 1999, 190, 617-627.

30. Grzywacz, B.; Dlubek, D.; Lange, A. NK cells become Ki-67+ in MLC and expend depending on the lack of ligand for KIR on stimulator cells in IL-2 supplemented MLC. Hum. Immunol. 2002, 63, 638-646.

31. Anderson, G.M.; Nakada, M.T.; DeWitte, M. Tumor necrosis factor-alpha in the pathogenesis and treatment of cancer. Curr. Opin. Pharmacol. 2004, 4, 314-320.

32. Mocellin, S.; Rossi, C.R.; Pilati, P.; Nitti, D. Tumor necrosis factor, cancer and anticancer therpy. Cytokine Growth Factor Rev. 2005, 16, 35-53.

33. Chen, B; Ning, M.; Yang, G. Effect of paeonol on antioxidant and immune regulatory activity in Hepatocellular carcinoma rats. Molecules 2012, 17, 4672-4683.

34. Kotoh, T.; Dhar, D.K.; Masunga, R.; Tabara, H.; Tachibana, M.; Kubota, H.; Kohno, H.; Nagasue, N. Antiangiogenic therapy of human esophageal cancers with thalidomide in nude mice. Surgery 1999, 125, 536-544.

35. Amat, N.; Upur, H.; Ablimit, A.; Matsidik, A.; Yusup, A.; Kijjoa, A. Immunomodulatory effects of Abnormal Sava Munsiq, a traditional Uighur medicine, on the combined stress mice. J. Ethnopharmacol. 2009, 122, 42-47.

Sample Availability: Not Available.

(C) 2013 by the authors; licensee MDPI, Basel, Switzerland. This article is an open access article distributed under the terms and conditions of the Creative Commons Attribution license (http://creativecommons.org/licenses/by/3.0/). 